\title{
Effects of repeated maternal betamethasone administration on growth and hypothalamic-pituitary-adrenal function of the ovine fetus at term
}

\author{
D M Sloboda ${ }^{1,2}$, J P Newnham ${ }^{3}$ and J R G Challis ${ }^{1,2}$ \\ ${ }^{1}$ Departments of Physiology and Obstetrics and Gynecology, University of Toronto, Toronto M5S 1A8, Canada \\ ${ }^{2}$ Medical Research Council of Canada Group in Fetal and Neonatal Health and Development \\ ${ }^{3}$ Department of Obstetrics, University of Western Australia, Perth, Australia 6008 \\ (Requests for offprints should be addressed to D Sloboda, Department of Physiology, Room 3205, Medical Sciences Building, University of Toronto, \\ 1 King's College Circle, Toronto, Ontario M5S 1A8, Canada; Email: d.sloboda@utoronto.ca)
}

\begin{abstract}
Synthetic glucocorticoids have become an important clinical tool with which to advance fetal lung maturation in women at risk of early preterm birth, and this has succeeded in reducing neonatal mortality and morbidity from respiratory distress syndrome. Although previous studies have shown that glucocorticoids have deleterious consequences on fetal development, there is little information regarding the effects of clinically relevant repeated maternal doses of glucocorticoids on fetal growth and hypothalamic-pituitary-adrenal (HPA) function. We hypothesised that repeated prenatal exposure to increased concentrations of glucocorticoids would alter fetal growth and HPA axis development. Pregnant ewes were injected with betamethasone $(0.5 \mathrm{mg} / \mathrm{kg})$ or vehicle at 104,111 and 118 days of gestation (term 150 days). Animals were sacrificed at 125 and 146 days of gestation, at which time fetal weights were recorded. Maternal and fetal blood samples were gathered and fetal tissue collected. Maternal oestradiol concentrations were significantly greater than those in controls at 125 days of gestation, but were not different at 146 days. Maternal plasma progesterone concentrations were similar between groups at both 125 and 146 days of gestation. Weight at birth was significantly reduced by $23 \%$ at 125 days and $19 \%$ at 146 days of gestation $(P<0 \cdot 05)$ after exposure to glucocorticoid. Cord plasma ACTH concentrations were not significantly different between groups at day 125 , but were significantly increased in day 146 fetuses of ewes that had received betamethasone $(P<0 \cdot 05)$. Cord plasma cortisol concentrations followed the same trend, although differences were not statistically significant. Cord plasma corticosteroid binding capacity (CBC) was significantly increased
\end{abstract}

at 125 days of gestation in fetuses of betamethasone-treated animals $(P<0 \cdot 05)$, but not at 146 days of gestation. To examine the mechanisms regulating the increase in cord plasma ACTH of 146-day fetuses, we used in situ hybridisation to determine the distribution and levels of mRNA encoding key pituitary and hypothalamic neuropeptides of the HPA axis. In pituitaries of 146-day fetuses, there were no significant differences in the regional pattern of distribution or amounts of pro-opiomelanocortin (POMC) mRNA between betamethasone-treated animals and controls, in either the pars intermedia or the inferior and superior regions of the pars distalis. Neither prohormone convertase (PC) -1 nor PC-2 mRNA levels in pituitaries of 146-day fetuses were significantly different between treatment groups. After maternal betamethasone, immunoreactive $\mathrm{ACTH}$ peptide content in the fetal pars distalis was not different but glucocorticoid receptor (GR) mRNA levels in the pars distalis were increased significantly $(P<0 \cdot 05)$. No significant difference in distribution pattern or concentrations of corticotrophin-releasing hormone $(\mathrm{CRH}) \mathrm{mRNA}$, GR mRNA, oxytocin mRNA and pre-proenkephalin mRNA were found in hypothalami from fetuses at 146 days of gestation after betamethasone treatment. We conclude that antenatal betamethasone given to pregnant sheep in a manner similar to that used in human obstetric practice results in reduced weight at birth at 125 and 146 days, and altered basal cord levels of plasma ACTH and corticosteroid binding capacity, but these changes are not reflective of changes in steady state concentrations of POMC and CRH mRNA in the fetal pituitary or hypothalamus.

Journal of Endocrinology (2000) 165, 79-91

\section{Introduction}

Liggins \& Howie (1972) first suggested the potential advantage of administering synthetic glucocorticoids to women at risk of early preterm birth in order to promote fetal lung maturity and prevent the development of neonatal respiratory disease. Recent practice has included repeated administration of synthetic glucocorticoids at 
weekly intervals to women at risk of early preterm birth in whom delivery has not occurred. However, diagnosis of preterm birth is difficult and women not at risk may be receiving antenatal glucocorticoids unnecessarily (Ballard \& Ballard 1995).

Exposure of the fetus to increased concentrations of corticosteroids may be detrimental to development. Various studies in animals have shown reductions in weight at birth (Jobe et al. 1998), alterations in organ (Johnson et al. 1981) and neuronal development (Uno et al. 1990, 1994, Dunlop et al. 1997), and increases in basal and stress-induced plasma cortisol concentrations postnatally (Uno et al. 1994) after prenatal glucocorticoids. These last observations suggest that chronic fetal exposure to glucocorticoid may alter the development of the hypothalamo-pituitary-adrenal HPA axis in utero. In the human, a reduction in birth weight and neonatal head circumference was related to an increasing number of maternal corticosteroid courses (French et al. 1999). Furthermore, an increased incidence of death from cardiovascular disease has been associated with a reduced head circumference, ponderal index and birth weight in man (Barker et al. 1993), potentially linking fetal exposure to increased glucocorticoids with increased risk of adult disease later in life.

A late gestational increase in endogenous plasma cortisol occurs in fetuses of many species and is responsible for prenatal enzyme activation within target tissues, necessary for tissue and organ maturation (Liggins 1994). The regulation of fetal HPA function and adrenal cortisol output is multifactorial. Corticotrophin-releasing hormone $(\mathrm{CRH})$ and arginine vasopressin (AVP) are the primary stimulators of corticotrophs within the pars distalis of the pituitary that synthesize the polypeptide precursor, proopiomelanocortin (POMC) and secrete adrenocorticotrophic hormone (ACTH) (Antolovich et al. 1991, Yang et al. 1991). Two prohormone convertase enzymes, prohormone convertase 1 (PC1) and prohormone convertase 2 (PC2), cleave POMC to generate ACTH and related peptides (Eipper \& Mains 1980). In the fetal pituitary, both the pars distalis and the pars intermedia express PC1 mRNA, whereas PC2 mRNA is highly localized to the pars intermedia (Bell et al. 1998). Other hypothalamic peptides, such as oxytocin (Kemppainen et al. 1993, Matthews 1999) and pre-proenkephalin (PENK) (Matthews \& Challis 1995a), can also influence corticotroph activity. Cortisol exerts negative feedback on fetal POMC synthesis (Norman et al. 1985, McMillen et al. 1990) after binding to type 2 glucocorticoid receptors (GR) in the hypothalamus and pituitary (Yang et al. 1990, Matthews \& Challis 1995b, 1997) and to hippocampal GR and type 1 mineralocorticoid receptors. Late in gestation in the fetal sheep, plasma ACTH and cortisol concentrations increase concurrently, despite the potential of negative feedback until birth occurs (Norman et al. 1985). This apparent paradox may be explained in part by correspond- ing increases in circulating plasma corticosteroid binding globulin $(\mathrm{CBG})$, the high-affinity binding protein for cortisol, which maintains a relatively low free cortisol concentration, thereby reducing the impact of cortisol negative feedback on pituitary ACTH output (Ballard et al. 1982, Berdusco et al. 1995).

Cortisol has a pivotal role in fetal growth and development and it is essential to regulate strictly the circulating glucocorticoid concentrations in the fetus. Although the effects of glucocorticoid exposure on the fetus have been well documented, very few studies have either evaluated the effects of clinically relevant glucocorticoid doses or replicated the method of glucocorticoid administration used in human obstetric practice. The long-term effects on the fetus of maternally administered glucocorticoids have not yet been ascertained. In addition, there is little information describing the mechanisms underlying either the change in fetal growth or the reported changes in fetal and neonatal endocrine function after antenatal exposure to glucocorticoid. Therefore, we determined the effects of repeated maternal glucocorticoid administration at approximately two-thirds of gestation on fetal growth and on the development of the fetal HPA axis. We hypothesised that repeated fetal exposure to glucocorticoids would decrease weight at birth and alter gene expression of key neuropeptides and receptors regulating fetal HPA function, thereby altering the fetal HPA endocrine profile.

\section{Materials and Methods}

\section{Animals}

Merino ewes were mated and singleton pregnancy was confirmed using ultrasound examination at 42 days of gestation (term 150 days). The sheep were transported to a research station at 90 days of gestation and were kept in pastures, to graze in a field environment. On the evening before injections and later delivery, sheep were brought into a nearby indoor facility.

\section{Experimental procedures}

All animals received an i.m. injection of $150 \mathrm{mg}$ medroxyprogesterone acetate (Depo Provera, Upjohn, Rydalmere, NSW, Australia) at 98 days of gestation. Pregnant sheep $(n=37)$ were allocated randomly to either control or treatment groups. Animals in the treatment group received i.m. injections of $0.5 \mathrm{mg} / \mathrm{kg}$ maternal weight betamethasone (Celestone Chronodose, Schering Plough, Baulkham Hills, NSW, Australia) at 104, 111 and 118 days of gestation. Control animals received saline injections at the same time points. The total dose of betamethasone was between 25 and $30 \mathrm{mg}$, which correlates closely with clinical doses used for fetal lung maturation in women at risk of early preterm birth (Liggins \& Howie 1972). This 
dose has previously been shown to improve lung function in fetal sheep (Ikegami et al. 1997). Ewes were sedated with maternal i.m. ketamine $(15 \mathrm{mg} / \mathrm{kg})$ and xylazine $(0 \cdot 1 \mathrm{mg} / \mathrm{kg}$, Troy Laboratories, Smithfield, NSW, Australia) and spinal anaesthesia was induced by injection of 3-4 $\mathrm{ml}$ lignocaine $(2 \%)$. The fetus was delivered through a midline hysterotomy and arterial blood samples were collected from the umbilical cord and from the maternal femoral vessels, after which the fetus was killed by a lethal dose of pentobarbitone $(30 \mathrm{mg} / \mathrm{kg})$. Cord blood gases $\left(\mathrm{PO}_{2}, \mathrm{PCO}_{2}\right.$, and $\left.\mathrm{pH}\right)$ were measured and samples were centrifuged at $2200 \mathbf{g}$ for $10 \mathrm{~min}$ and the plasma stored at $-20^{\circ} \mathrm{C}$ until required for further analysis. At 125 days of gestation, 22 animals were killed and fetal weights recorded (control $n=10$; betamethasone $n=12$ ). Tissues from 11 of these animals were collected for further analyses (control $n=5$; betamethasone $n=6$ ). At 146 days of gestation, control $(n=7)$ and betamethasone-treated $(n=8)$ animals were killed, fetal weights recorded and tissue collected for further analyses. Fetal hypothalamic blocks and pituitaries were slow frozen on dry ice for in situ hybridization and immunohistochemistry (Matthews et al. 1994). The procedures were approved by the Institutional Ethics Committees of the Western Australian Department of Agriculture and the Animal Care Committee of the University of Toronto, according to the guidelines of the Canadian Council for Animal Care.

Measurement of fetal plasma $A C T H$, cortisol and $C B G$, and maternal plasma cortisol, oestrogen and progesterone

Plasma immunoreactive (ir)-ACTH concentrations were measured using a commercial RIA kit (Incstar, Stillwater, MN, USA) previously validated for use in the fetal sheep (Norman et al. 1985). The intra-assay coefficient of variation was $15 \%$, and the mean assay sensitivity $6.5 \mathrm{pg} / \mathrm{ml}$. The ACTH antibody crossreacts $<0.01 \%$ with $\alpha$-melanocyte stimulating hormone (MSH), $\beta-\mathrm{MSH}$, $\beta$-endorphin and $\beta$-lipotropin (LPH) (Incstar). Plasma cortisol concentrations were quantified by RIA after extraction with diethyl ether. The antibody characteristics and assay validation for measurement of cortisol in fetal sheep plasma have been described previously (Challis et al. 1981). The intra-assay coefficient of variation was $5 \%$. Fetal plasma concentrations of CBG were measured as corticosteroid binding capacity (CBC), determined using the saturation binding assay of Ballard et al. (1982), with modifications described previously (Challis et al. 1985). The intra-assay coefficient of variation was 3\%. Maternal plasma oestradiol and progesterone concentrations were quantified by RIA after extraction with diethyl ether. The antibody characteristics and assay validation for measurements in the sheep have been described previously (Challis et al. 1981). The intra-assay coefficient of variation was 15\%. For each hormone and CBC, all samples were analysed in a single assay.

\section{Pituitary ACTH content}

The pars distalis was separated from the pars intermedia in those frozen 146-day pituitaries that remained after cryosectioning for in situ hybridisation. Each pars distalis was weighed and homogenised (PT200 Homogeniser, Polytron, Kinematica AG, Switzerland) in extraction buffer $(1 \mathrm{M} \mathrm{HCl}, 5 \% \mathrm{v} / \mathrm{v}$ formic acid, $1 \% \mathrm{w} / \mathrm{v} \mathrm{NaCl}, 1 \% \mathrm{v} / \mathrm{v}$ trifluoroacetic acid) (Bennett et al. 1981). Samples were centrifuged at $1775 \mathrm{~g}$ for $10 \mathrm{~min}$ at $4{ }^{\circ} \mathrm{C}$. ir-ACTH concentrations were analysed using a commercial RIA (Incstar). Protein content was determined using the method of Bradford (1976) and ACTH(1-39) concentrations were expressed per $\mathrm{mg}$ of protein. Intra-assay coefficient of variation for the ACTH assay was $8 \%$, and all samples were analysed in a single assay.

In situ hybridisation of 146-day fetal pituitary POMC, PC1 and PC2 mRNA and hypothalamic CRH, GR, AVP, oxytocin and PENK $m R N A$

The method for in situ hybridisation has been described previously in detail (Matthews et al. 1991, 1994). Briefly, frozen pituitaries and hypothalami of the 146-day fetal group were sectioned (12 $\mu \mathrm{m}$ coronal sections) using a cryostat (Tissue-Tek, Miles Canada, Etobicoke, Canada) and mounted onto poly-L-lysine (Sigma Chemical, St Louis, MO, USA)-coated slides, dried and fixed in $4 \%$ paraformaldehyde for $5 \mathrm{~min}$, rinsed in PBS $(2 \times 1 \mathrm{~min})$, dehydrated in an alcohol series and stored in 95\% alcohol at $4{ }^{\circ} \mathrm{C}$ until required for hybridisation. Pituitary sections were incubated with $\alpha-{ }^{35}$ S-labelled, 45-mer oligonucleotide antisense probes. In the pituitary, antisense probes were complementary to bases 711-756 of the porcine POMC gene (Gossard et al. 1986), bases 231-275 of the porcine PC1 gene (Dai et al. 1995), bases 153-197 of the porcine PC2 gene (Seidah et al. 1992), and bases 146-191 of the ovine GR gene (Yang et al. 1992). Hypothalamic sections were incubated with $\alpha-{ }^{35} \mathrm{~S}-$ labelled, 45-mer oligonucleotide antisense probes complementary to bases 503-547 of the ovine $\mathrm{CRH}$ gene (Matthews et al. 1991), bases 146-191 of the GR gene (Yang et al. 1992), bases 1-45 of the bovine PENK gene (Noda et al. 1982), and to bases 771-816 of the ovine oxytocin-neurophysin gene (Ivell et al. 1990). All probes have been characterised and used previously (Matthews et al. 1991, 1993, Broad et al. 1993, Matthews \& Challis 1995a, Jeffray et al. 1998). Control slides were incubated with $\alpha_{-}{ }^{35}$ S-labelled, 45-mer oligonucleotide random sequences, which did not correspond to the antisense probes. All slides were exposed together with ${ }^{14} \mathrm{C}$ standards (American Radiochemical, St Louis, MO, USA) to ensure analysis within the linear range of the autoradiographic film (Biomax, Kodak). The relative optical density (ROD) of the signal on the film of 9-14 sections per tissue was quantified using a computerised image 
Table 1 Maternal arterial oestradiol, progesterone and cortisol concentrations, and CBC at 125 and 146 days of gestation after administration of either saline or betamethasone. Values are mean \pm S.E.M.

\begin{tabular}{|c|c|c|c|c|}
\hline & \multicolumn{2}{|c|}{125 days of gestation } & \multicolumn{2}{|c|}{146 days of gestation } \\
\hline & $\begin{array}{l}\text { Control } \\
(n=5)\end{array}$ & $\begin{array}{l}\text { Betamethasone } \\
(n=6)\end{array}$ & $\begin{array}{l}\text { Control } \\
(n=7)\end{array}$ & $\begin{array}{l}\text { Betamethasone } \\
(n=8)\end{array}$ \\
\hline Oestradiol (pg/ml) & $11 \cdot 1 \pm 7 \cdot 3$ & $58 \cdot 0 \pm 10 \cdot 2^{*}$ & $27 \cdot 6 \pm 10 \cdot 4$ & $42 \cdot 0 \pm 12 \cdot 1$ \\
\hline Progesterone (ng/ml) & $9 \cdot 8 \pm 2 \cdot 4$ & $4 \cdot 2 \pm 0 \cdot 5$ & $5 \cdot 2 \pm 1 \cdot 1$ & $5 \cdot 4 \pm 1 \cdot 5$ \\
\hline Cortisol (ng/ml) & $16 \cdot 7 \pm 4 \cdot 2$ & $7 \cdot 3 \pm 2 \cdot 6$ & $10 \cdot 4 \pm 2 \cdot 1$ & $18 \cdot 7 \pm 4 \cdot 2$ \\
\hline $\mathrm{CBC}(\mathrm{ng} / \mathrm{ml})$ & $10 \cdot 9 \pm 0.03$ & $10 \cdot 4 \pm 0 \cdot 2$ & $17 \cdot 0 \pm 0 \cdot 02$ & $25 \cdot 0 \pm 0 \cdot 1$ \\
\hline
\end{tabular}

analysis system (Imaging Research, St Catharines, Ontario, Canada). Values represent an average density over the area measured, after background values were subtracted. All control and experimental sections were processed together to allow direct comparisons between groups. Because pituitary POMC mRNA was distributed regionally, analysis of the superior region (region around the pars intermedia) and the inferior region (region at the base of the pars distalis) was performed separately, in addition to analysis of the entire pars distalis. For hypothalamic sections, values represent total paraventricular nucleus (PVN) signal.

\section{Immunohistochemistry}

Immunohistochemical detection of ir-ACTH was performed on $12 \mu \mathrm{m}$ frozen pituitary sections prepared as above for in situ hybridization. A polyclonal antibody to human ACTH(1-24) (Dako, Carpinteria, CA, USA) was used with avidin-biotin-peroxidase reagents (Vectastain ABC Kit, Vector Laboratories, Burlingame, CA, USA) as described previously (Jacobs et al. 1991). Adjacent sections were incubated in the presence of excess antigen, to provide negative controls.

\section{Data analysis}

Changes in weight at birth were analysed using Student's $t$-test for each group (125 days and 146 days) separately. Changes in cord plasma $\mathrm{pH}, \mathrm{PO}_{2}, \mathrm{PCO}_{2}$, ir-ACTH and $\mathrm{CBG}$, and maternal plasma oestradiol at both 125 and 146 days of gestation were analysed using Student's $t$-test. Pituitary POMC, GR, PC1 and PC2 mRNA, and hypothalamic CRH, AVP, GR, oxytocin and PENK mRNA at 146 days of gestation were expressed as ROD and analysed using Student's $t$-test. The content of ir-ACTH in the pars distalis tissue at 146 days, cord plasma cortisol and maternal progesterone at 125 and 146 days of gestation were not normally distributed, and were analysed using the Mann-Whitney Rank Sum test. Statistical significance was determined as $P<0 \cdot 05$. All values are presented as mean \pm standard error (S.E.M.) (Sigmastat, Jandel Scientific, San Rafael, CA, USA).

\section{Results}

Effect of prenatal betamethasone exposure on concentrations of maternal plasma oestradiol, progesterone and cortisol, and CBC

Maternal plasma oestradiol and progesterone were measured in order to evaluate whether maternal exposure to betamethasone induced the pattern of increase in circulating oestradiol and decrease in progesterone seen with onset of spontaneous and induced parturition in sheep (Liggins et al. 1973). Maternal plasma oestradiol concentrations were significantly greater after betamethasone treatment at 125 days of gestation, 1 week after the final betamethasone injection $(P<0 \cdot 05$; Table 1$)$, but were not significantly different from controls at 146 days of gestation. Maternal plasma progesterone concentrations were similar between groups (Table 1). Neither maternal mean plasma cortisol concentration nor CBC was altered significantly after maternal exposure to betamethasone (Table 1).

\section{Cord blood gases and $\mathrm{pH}$}

Fetal status at the time of delivery was assessed by measurement of cord blood $\mathrm{pH}$ and blood gas measurements. Mean cord arterial $\mathrm{PO}_{2}, \mathrm{PCO}_{2}$ and $\mathrm{pH}$ were similar in both groups (125 and 146 days of gestation) after betamethasone treatment (Table 2).

\section{Effect of prenatal betamethasone exposure on weight at birth}

Fetal weight at 125 days of gestation after repeated exposure to betamethasone in utero was significantly reduced, by $23 \%(P<0 \cdot 05$; Table 2$)$. At 146 days of gestation, 30 days after the last course of betamethasone, fetal weight was reduced significantly, by $19 \%$, compared with that of controls $(P<0 \cdot 05$; Table 2$)$. 
Table 2 Cord plasma $\mathrm{pH}, \mathrm{PO}_{2}, \mathrm{PCO}_{2}$ and fetal weight at 125 and 146 days of gestation after prenatal exposure to either saline or bethamethasone. Values are mean \pm S.E.M.

\begin{tabular}{|c|c|c|c|c|}
\hline & \multicolumn{2}{|c|}{125 days of gestation } & \multicolumn{2}{|c|}{146 days of gestation } \\
\hline & $\begin{array}{l}\text { Control } \\
(n=5) \dagger\end{array}$ & $\begin{array}{l}\text { Betamethasone } \\
(n=6) \ddagger\end{array}$ & $\begin{array}{l}\text { Control } \\
(n=7)\end{array}$ & $\begin{array}{l}\text { Betamethasone } \\
(n=8)\end{array}$ \\
\hline $\mathrm{pH}$ & $7 \cdot 32 \pm 0 \cdot 03$ & $7 \cdot 41 \pm 0 \cdot 02$ & $7 \cdot 31 \pm 0 \cdot 02$ & $7 \cdot 33 \pm 0.03$ \\
\hline $\mathrm{PO}_{2}(\mathrm{mmHg})$ & $9 \cdot 1 \pm 1 \cdot 0$ & $10 \cdot 4 \pm 1 \cdot 1$ & $11 \cdot 4 \pm 1 \cdot 2$ & $10 \cdot 0 \pm 1 \cdot 0$ \\
\hline $\mathrm{PCO}_{2}(\mathrm{mmHg})$ & $54 \cdot 3 \pm 2 \cdot 0$ & $51 \cdot 4 \pm 1 \cdot 9$ & $52 \cdot 9 \pm 2 \cdot 7$ & $51 \cdot 1 \pm 2 \cdot 2$ \\
\hline Fetal weight (kg) & $2 \cdot 7 \pm 0 \cdot 5$ & $2 \cdot 1 \pm 0 \cdot 3^{*}$ & $4 \cdot 6 \pm 0 \cdot 3$ & $3 \cdot 8 \pm 0 \cdot 2^{*}$ \\
\hline
\end{tabular}

For fetal weight measurements: $\nmid n=10 ; \ddagger n=12$ (see Methods). ${ }^{*} P<0 \cdot 05$ compared with control.

Table 3 Cord plasma cortisol and ACTH concentrations, and CBC, at 125 and 146 days of gestation, after prenatal exposure to either saline or betamethasone. Values are mean \pm S.E.M.

\begin{tabular}{|c|c|c|c|c|}
\hline & \multicolumn{2}{|c|}{125 days of gestation } & \multicolumn{2}{|c|}{146 days of gestation } \\
\hline & $\begin{array}{l}\text { Control } \\
(n=5)\end{array}$ & $\begin{array}{l}\text { Betamethasone } \\
(n=6)\end{array}$ & $\begin{array}{l}\text { Control } \\
(n=7)\end{array}$ & $\begin{array}{l}\text { Betamethasone } \\
(n=8)\end{array}$ \\
\hline ACTH $(p g / m l)$ & $29 \cdot 5 \pm 3 \cdot 0$ & $36 \cdot 0 \pm 10 \cdot 1$ & $54 \cdot 6 \pm 5 \cdot 2$ & $82 \cdot 1 \pm 6 \cdot 7^{*}$ \\
\hline Cortisol (ng/ml) & $3 \cdot 2 \pm 0 \cdot 6$ & $1 \cdot 9 \pm 0 \cdot 3$ & $12 \cdot 5 \pm 2.2$ & $35 \cdot 7 \pm 17 \cdot 8$ \\
\hline $\mathrm{CBC}(\mathrm{ng} / \mathrm{ml})$ & $17 \cdot 3 \pm 3 \cdot 2$ & $47 \cdot 9 \pm 10 \cdot 7^{*}$ & $57 \cdot 3 \pm 17 \cdot 7$ & $54 \cdot 3 \pm 14 \cdot 4$ \\
\hline
\end{tabular}

Basal cord plasma ir-ACTH, cortisol and CBG concentrations

At 125 days of gestation, mean cord plasma ir-ACTH concentrations were not significantly different from those in controls after repeated exposure to glucocorticoid (Table 3). At 146 days, however, cord plasma irACTH concentrations were significantly greater in betamethasone-treated fetuses $(P<0 \cdot 05$; Table 3$)$. Mean cord plasma cortisol concentrations at 125 days of gestation were not altered after glucocorticoid exposure and, although cord plasma cortisol concentrations at 146 days tended to be greater than those in controls, these differences did not reach statistical significance (Table 3). Plasma CBG concentration, measured as CBC, was significantly greater at 125 days of gestation after prenatal exposure to betamethasone $(P<0 \cdot 05$; Table 3$)$. This difference was not present, however, at 146 days of gestation.

Effect of prenatal betamethasone exposure on pituitary ir-ACTH peptide content at 146 days of gestation

In order to evaluate the mechanisms underlying the increase in cord ACTH concentrations at term, we determined the ir-ACTH(1-39) peptide content in pituitary tissue, in addition to conducting immunohistochemical localisation of ir-ACTH. Positive ir-ACTH staining was observed in both the pars distalis and the pars intermedia, after betamethasone exposure, in tissue from fetuses at 146 days of gestation (Fig. 1A, B). Tissue sections from betamethasone-treated fetuses showed less staining for ir-ACTH in the pars distalis but similar ir-ACTH in the pars intermedia (Fig. 1A, B). Adjacent sections incubated with antibody preabsorbed with an excess of human ACTH(1-24) showed no positive staining for ir-ACTH (Fig. 1C). In order to quantify changes in pituitary ACTH content, protein was extracted from the pars distalis and analysed for ir-ACTH. Concentrations of pars distalis ir-ACTH (pg/mg protein) in the betamethasone-treated animals were not statistically different from those in controls (controls: $7 \cdot 6 \pm 1 \cdot 2 \mathrm{pg} / \mathrm{mg}, n=7$; betamethasone: $5 \cdot 0 \pm 0 \cdot 8 \mathrm{pg} / \mathrm{mg}, n=8 ; P=0 \cdot 09)$.

Effect of prenatal betamethasone exposure on levels of pituitary POMC, PC1, PC2 and GR mRNA at 146 days of gestation

POMC mRNA distribution was not altered by prenatal exposure to betamethasone exposure (Fig. 2A, B) and was similar to that seen previously in fetal sheep at this time in gestation (Matthews et al. 1994). Pituitary levels of POMC mRNA were significantly greater in the inferior region of the pars distalis than in the superior region, in both control 

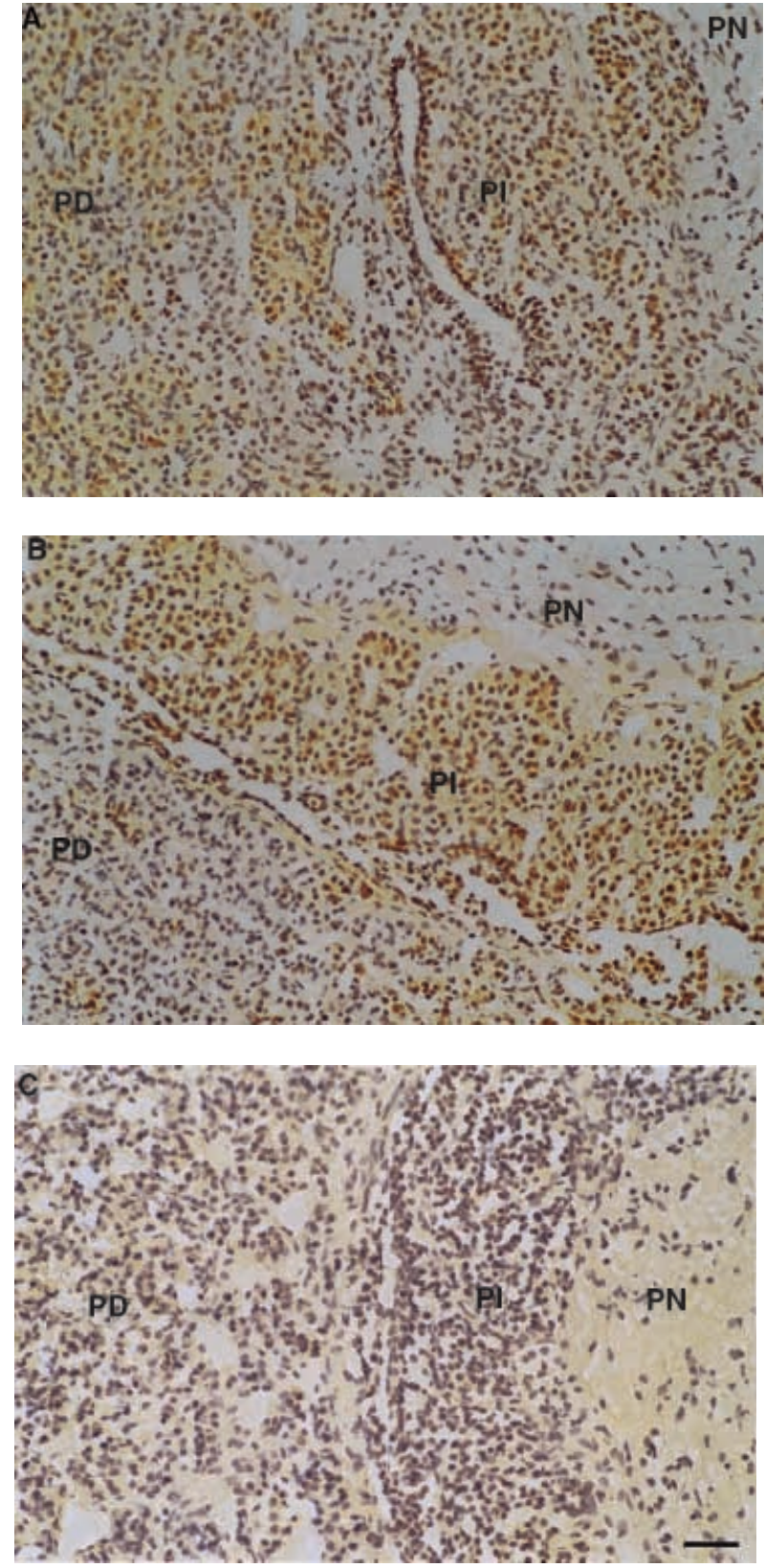

Figure 1 Photographs of immunohistochemical staining of ACTH in the pars distalis (PD) and the pars intermedia (PI) of saline- (A) and betamethasone- (B) treated animals at 146 days of gestation. (C) Preabsorption control. PN, pars nervosa. Scale bar represents $50 \mu \mathrm{m}$.

and betamethasone-treated groups $(P<0 \cdot 05)$, but were not significantly different between treatment groups (Fig. 3C). Neither PC1 nor PC2 mRNA levels or distribution were altered after betamethasone exposure (Fig. 2C-F). Maternal betamethasone administration increased GR mRNA levels significantly in the pars distalis of 146-day fetal pituitaries (Fig. 2G, H, Fig. 4; P<0.05). GR mRNA was not detected in the pars intermedia.

Effect of prenatal betamethasone exposure on hypothalamic CRH, GR, oxytocin, and PENK $m R N A$ at 146 days of gestation

The distribution of CRH, GR (Fig. 5A-D), oxytocin and PENK mRNA (data not shown) in the paraventricular nucleus of 146 day fetal hypothalami was not altered by prenatal exposure to betamethasone. Levels of $\mathrm{CRH}$ and GR mRNA, as determined by computerised image analysis were similar in both groups (Fig. 5F, G). Levels of oxytocin and PENK mRNA were also similar in both groups after maternal betamethasone administration (data not shown).

\section{Discussion}

We have demonstrated that clinically relevant maternal administration of betamethasone in pregnant sheep at mid-gestation results in significant reductions in weight at birth. Repeated fetal glucocorticoid exposure at that time of gestation resulted in significant increases in basal cord plasma CBC at 125 days of gestation and significant increases in basal ACTH concentrations at 146 days of gestation. Plasma cortisol concentrations showed a trend similar to that in ACTH values, but the differences did not reach statistical significance. It appears that these changes were not associated with detectable alterations in the levels of mRNA encoding key neuropeptides of the HPA axis in either the fetal pituitary or the hypothalamus.

The increase in cord plasma ACTH is unlikely to be related to the onset of labour, as maternal oestradiol and progesterone concentrations were not significantly different between the groups at 146 days of gestation, and neither group exhibited the pattern of maternal oestradiol or progesterone change characteristic of parturition. Maternal oestradiol concentrations were increased at day 125 , closer to the time of betamethasone administration, reproducing the changes reported by Liggins et al. (1973) after fetal glucocorticoid treatment. We cannot exclude the possibility that betamethasone stimulated prostaglandin production in the fetal placenta (Challis et al. 1999), and that an increase in fetal circulating prostaglandins stimulated an increase in fetal ACTH secretion (Louis et al. 1976, Ratter et al. 1979). We did not, however, collect fetal blood samples in a manner appropriate to measure fetal prostaglandin $\mathrm{E}_{2}$.

We reasoned, therefore, that the increase in cord plasma ACTH was the result of functional changes in the fetal HPA axis after exposure to increased glucocorticoids. Increased cord plasma ACTH concentrations at 146 days of gestation in this study were not accompanied by 

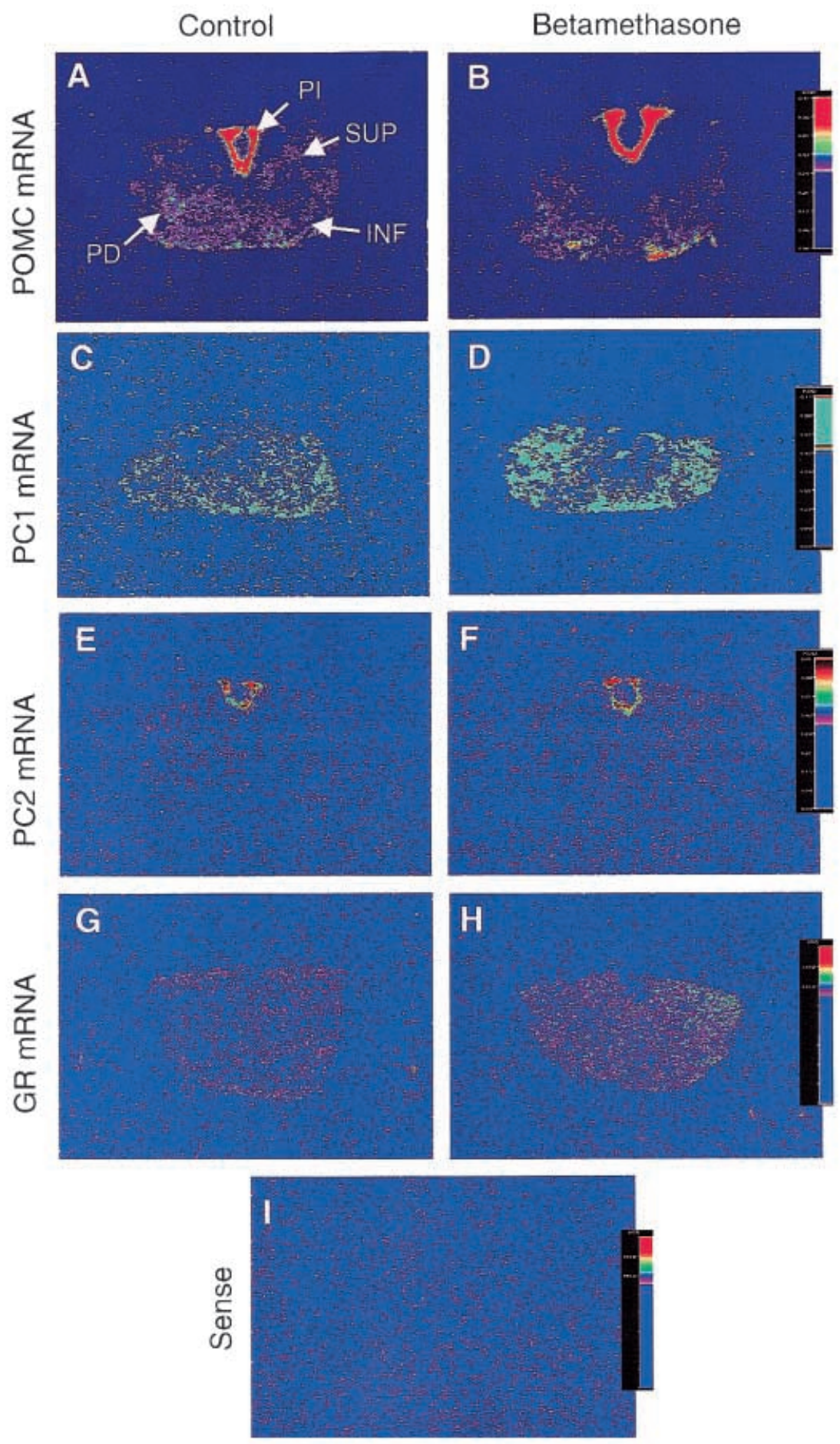

Figure 2 Localisation of POMC (A, B), PC1 (C, D), PC2 (E, F), and GR (G, H) mRNA in the pars distalis (PD) and pars intermedia (PI) of 146-day fetal pituitaries after in situ hybridisation of coronal sections with ${ }^{35}$ S-labelled oligonucleotide probes, after administration of either saline or betamethasone. Images are colour-enhanced and scales represent relative intensity of signal. Control sections were incubated with random nonsense sequences and showed no signal; a representative example is shown in I. SUP, superior region; INF, inferior region. 
A
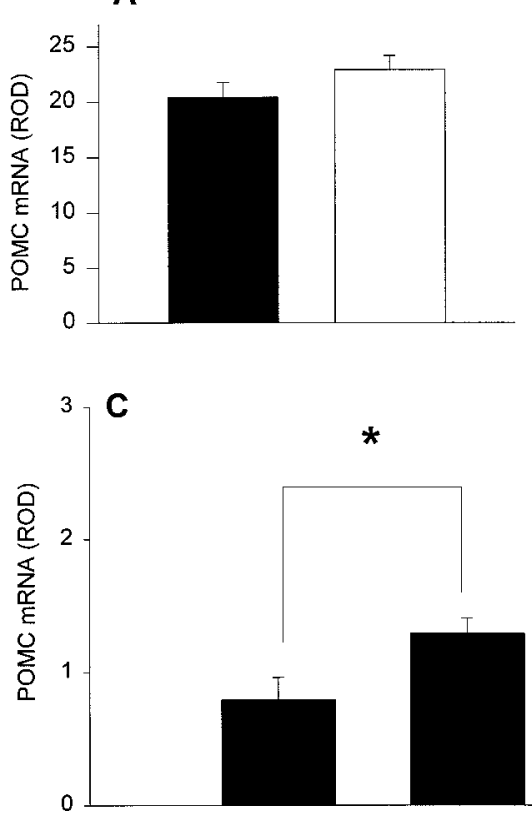

B

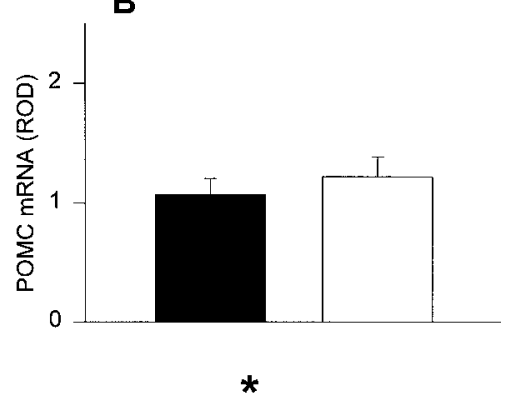

Figure 3 Bar graph illustrating densitometric analysis of POMC mRNA levels in coronal sections of the pars intermedia (A), total pars distalis (B), and differential distribution in the superior and inferior regions of the pars distalis $(C)$ of 146-day fetal pituitaries after administration of either saline $(\boldsymbol{\square})$ or betamethasone $(\square)$. Values are presented as relative optical density (ROD) and are mean \pm S.E.M. ${ }^{*} P<0 \cdot 05$.

significant changes in precursor POMC mRNA levels in either the pars intermedia or the pars distalis. Therefore the term increase in basal ACTH concentrations is probaby not a result of increased transcription, although we did not evaluate mRNA stability or transcriptional activity. It remains possible that small changes in steadystate POMC mRNA were present, but these differences could not be detected by in situ hybridization. The relative distribution of PC1 and PC2 mRNA levels within the pituitary was consistent with that reported in other studies (Marcinkiewicz et al. 1994, Bell et al. 1998). However, we did not measure prohormone convertase enzymatic activity, and PC1 and PC2 are not localised solely to the corticotrophs in the pars distalis, therefore we cannot firmly conclude that POMC processing is unaffected by exposure to glucocorticoid.

Positive ir-ACTH staining in the cells of the pars intermedia of 146-day pituitaries of fetuses treated with betamethasone was similar to that of control pituitaries. Less staining was observed, however, in the pars distalis of treated pituitaries. These observations are consistent with those of Jeffray et al. (1998), who reported a decrease in the number of ir-ACTH-positive corticotrophs in the fetal pars distalis after $96 \mathrm{~h}$ of fetal cortisol infusion, but no change in the pars intermedia. Content of ACTH(1-39) in the pars distalis was similar in 146-day fetuses of both groups. It remains possible that other sites of POMC production, such as the lung or placenta, may contribute to the increase in cord plasma ACTH (Cudd \& Wood 1995, Jeffray et al. 1999), after antenatal glucocorticoid treatment - effects that could be mediated by placental CRH (Jones et al. 1989).

Negative feedback is an important regulator of cortisol synthesis and secretion in the fetal HPA axis, through glucocorticoid binding to type II receptors (GR) in the PVN and in the pars distalis to reduce CRH and POMC production. The exact role of GRs in the pituitary, however, remains unclear. In the fetal sheep, GR mRNA and protein levels in the pars distalis increase at term (Yang et al. 1990, Matthews et al. 1995). There are no studies that have evaluated the effect of repeated maternal betamethasone administration on pituitary or hypothalamic GR mRNA levels, receptor number or activity in the fetal sheep. The increase in GR mRNA levels that we observed in the pars distalis of fetuses at day 146 of gestation after betamethasone treatment is consistent with the increase in pituitary GR seen at term as endogenous cortisol increases (Yang et al. 1990, 1992). This change may contribute to the effect of cortisol in promoting an increased output of $\mathrm{ACTH}(1-39)$ relative to largemolecular-weight POMC peptides by corticotrophs treated concurrently with CRH in vitro (Durand et al. 1986). Although mean cord cortisol concentrations in 


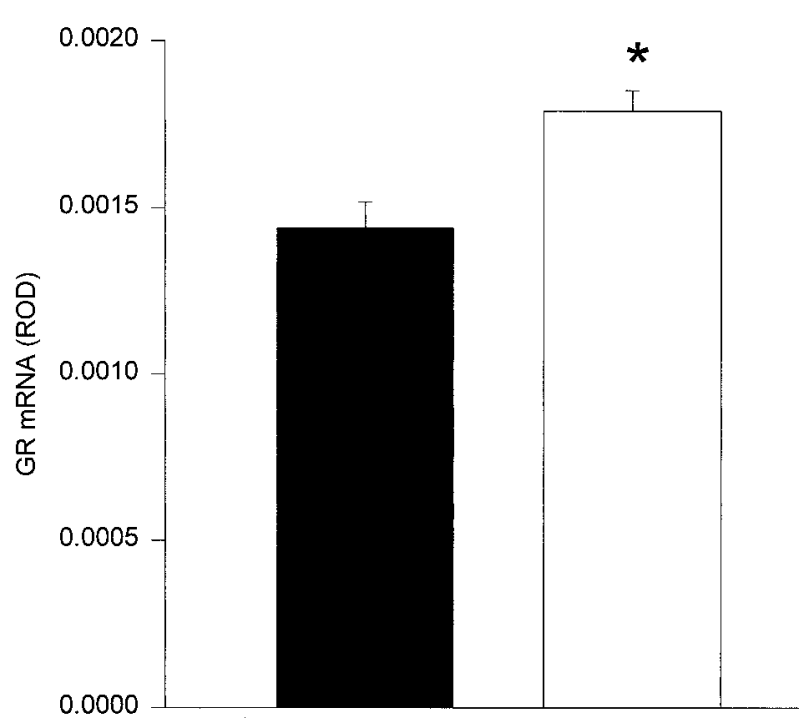

Figure 4 Bar graph illustrating densitometric analysis of GR mRNA levels in coronal sections of the entire pars distalis of 146-day fetal pituitaries after administration of either saline ( $\mathbf{\square})$ or

betamethasone $(\square)$. Values are presented as relative optical density (ROD) and are mean \pm S.E.M. ${ }^{*} P<0 \cdot 05$.

betamethasone-treated animals at term were threefold greater than those in controls, consistent with ACTH patterns, there was variability between individual animals and the cortisol values were not statistically different between groups. Thus we did not find significant increases in either cord cortisol or pituitary GR mRNA after betamethasone treatment.

Our data suggest that increases in cord plasma ACTH are not associated with changes in mRNA levels of hypothalamic neuropeptides. Matthews et al. (1995) reported that fetal cortisol infusion late in gestation did not alter basal CRH or AVP mRNA levels, but did suppress hypoxaemia-induced increases in CRH mRNA levels (Matthews \& Challis 1995b). Therefore glucocorticoids have differential effects on basal and stimulated levels of CRH mRNA. Our data also suggest that it is unlikely that increases in cord plasma ACTH are the result of changes in steady-state expression of oxytocin or PENK. A substantial body of evidence exists to suggest that fetal exposure to glucocorticoid results in changes in hippocampal GR and mineralocorticoid receptors (Meaney \& Aitken 1985, Sapolsky et al. 1990, Uno et al. 1994). In the present study, if such changes did occur, they did not result in detectable alterations in levels of mRNA encoding key hypothalamic neuropeptides or pituitary POMC. Nevertheless, such measurements will be of interest in the context of long-term programming of HPA function by antenatal corticosteroids.

Plasma CBC was significantly increased at 125 days of gestation after betamethasone treatment. It has been suggested previously that an increase in fetal plasma
CBG late in gestation maintains low concentrations of circulating cortisol and therefore maintains low negative feedback on the pituitary and the hypothalamus (Ballard et al. 1982, Berdusco et al. 1994, 1995). Glucocorticoids have been shown to increase plasma CBC and hepatic CBG mRNA in fetal sheep (Berdusco et al. 1994). We suggest therefore, that repeated fetal exposure to betamethasone between days 104 and 118 resulted in an increase in CBG production and an increase in plasma CBC measured at 125 days of gestation. In turn, CBG binds circulating cortisol, resulting in a decrease in negative feedback at the level of the hypothalamus/ pituitary and an increase in ACTH secretion that persists through later gestation, even though CBG concentrations have been restored to control values. In effect, maternal betamethasone alters the set point(s) of the fetal HPA negative feedback.

Our results are consistent with others that have shown changes in fetal or newborn circulating ACTH and cortisol concentrations following in utero exposure to betamethasone (Uno et al. 1994). Uno et al. (1990) found that the offspring of pregnant rhesus monkeys exposed to suprapharmacological doses of betamethasone showed increases in both basal and stimulated concentrations of ACTH and cortisol at 10 months of age compared with controls (Uno et al. 1990). Recent data in humans also link reductions in fetal growth with alterations in circulating glucocorticoids (Phillips et al. 1998). It has been reported that fasting plasma cortisol concentrations in 64-year-old men were inversely related to their birth weight, and that increased plasma cortisol concentrations were significantly associated with an increase in blood pressure, plasma glucose and insulin resistance (Phillips et al. 1998). These data support the hypothesis that an adverse intrauterine environment can permanently reset the developing fetal HPA axis, leading to an increased risk of adult diseases. It is possible that precocious exposure of the fetus to glucocorticoids creates an adverse intrauterine environment within which this may occur.

Exposure to glucocorticoid results in reductions in weight at birth (Reinisch et al. 1978, Johnson et al. 1981, Jobe et al. 1998) - a finding that we have substantiated using smaller amounts of steroid in the present study. Organ weights from a larger cohort of animals treated alongside this group have been published elsewhere and showed reductions in liver, brain and kidney weight and a significant increase in the brain:liver weight ratio (Newnham et al. 1999). Treatment of pregnant rhesus monkeys with betamethasone resulted in reductions in fetal brain, liver, pancreas, heart and adrenal weights at term (Johnson et al. 1981). A recent report by French et al. (1999) provides clear evidence that decreased birth weight ratios of singleton infants of mothers treated with prenatal glucocorticoids are associated with the number of glucocorticoid courses: head circumference analyses showed significant reductions when the mother had received more 

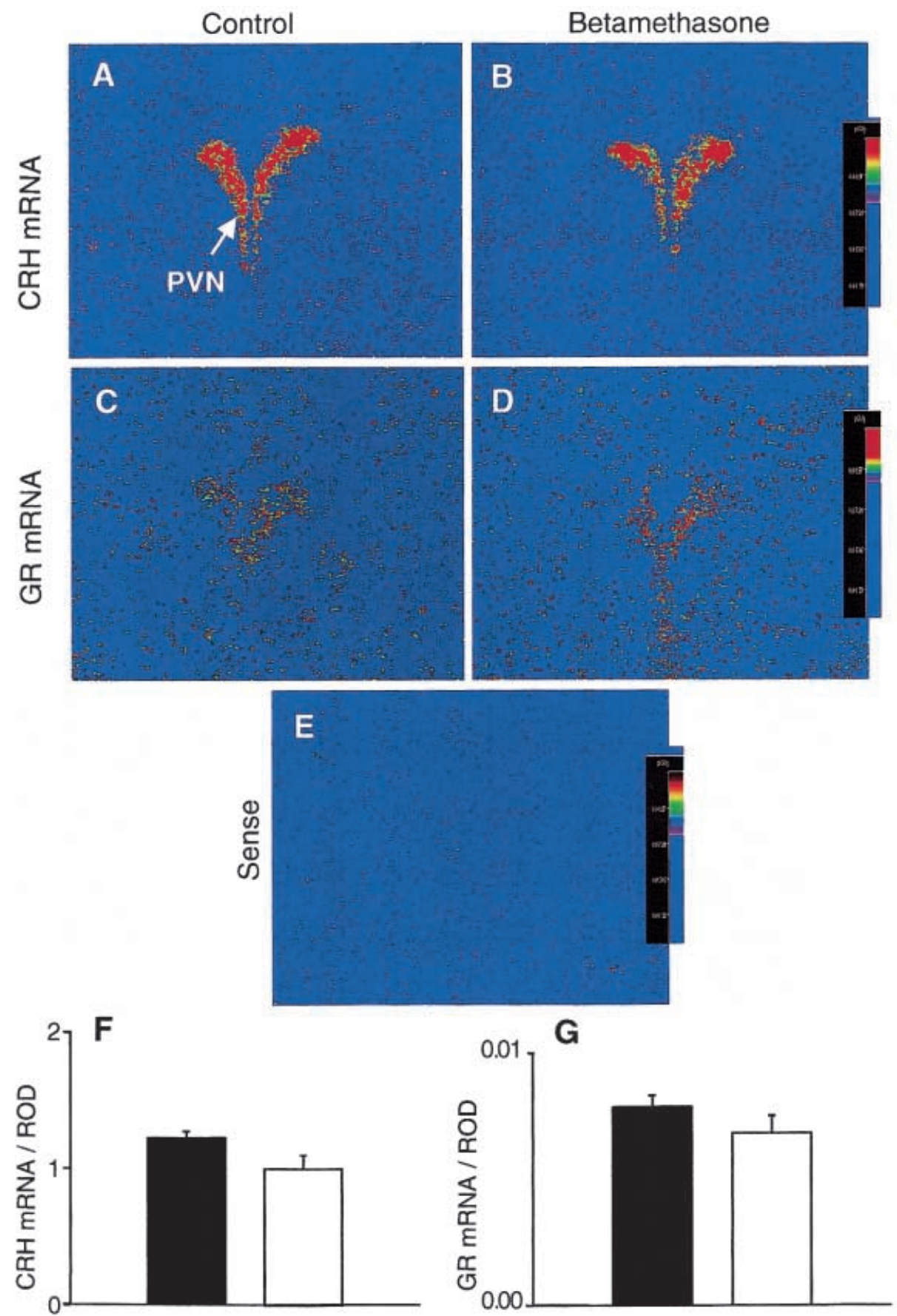

Figure 5 Localisation of $\mathrm{CRH}(\mathrm{A}, \mathrm{B})$, and GR (C, D) mRNA in the PVN of 146-day fetal hypothalami after in situ hybridisation of coronal sections with ${ }^{35}$ S-labelled oligonucleotide probes, after administration of either saline or betamethasone. Images are colour-enhanced and scales represent relative intensity of signal. Control sections were incubated with random nonsense sequences and showed no signal; a representative example is shown in $\mathrm{E}$. The bar graph illustrates the results of densitometric analysis of CRH (F) and GR (G) mRNA levels in coronal sections of the entire PVN of 146-day fetal hypothalami after administration of either saline ( $\mathbf{\square})$ or betamethasone ( $\square$ ). Values are presented as relative optical density (ROD) and are mean \pm S.E.M. 
than one glucocorticoid course (French et al. 1999). The mechanisms altering fetal growth, however, remain unknown. Insulin-like growth factors (IGFs) are generally believed to influence fetal growth by stimulating cell proliferation (D'Ercole 1987), and it has been proposed that an increase in endogenous fetal glucocorticoid regulates IGF-II mRNA expression and thereby regulates fetal growth, especially later in gestation (Li et al. 1993). It is possible that the reduction in fetal growth after repeated exposure to betamethasone in this study may be mediated through a reduction in tissue-specific IGF-II expression. Further studies are required to investigate this possibility fully. We suggest, however, that maternal administration of betamethasone between days 104 and 118 resulted in a shift in the fetal growth trajectory to a parallel but lower profile, resulting in similar differences in weight between treated animals and controls at term, as at day 125 of gestation.

This is the first study to evaluate levels of mRNA encoding the key pituitary and hypothalamic neuropeptides that regulate the fetal HPA axis after repeated fetal exposure to clinically relevant doses of glucocorticoids. We suggest that repeated maternal administration of betamethasone may produce long-term changes in growth and the development of the fetal HPA axis. We speculate that these observations raise the possibility that corticosteroids administered during the course of pregnancy to promote maturational changes in the fetus may have adverse consequences on both short-term and long-term fetal development.

\section{Acknowledgements}

We thank Professors Stephen G Matthews and Alan Jobe for their interest in these studies. This work was supported by the Medical Research Council of Canada (MRC Group in Fetal and Neonatal Health and Development) and the Women and Infants Research Foundation at King Edward Memorial Hospital and the NHMRC of Australia (Project Grant 981406).

\section{References}

Antolovich GC, McMillen IC, Robinson PM, Silver M, Young IR \& Perry RA 1991 The effect of hypothalamo-pituitary disconnection on the functional and morphologic development of the pituitaryadrenal axis in the fetal sheep in the last third of gestation. Neuroendocrinology 54 254-261.

Ballard PL \& Ballard RA 1995 Scientific basis and therapeutic regimens for use of antenatal glucocorticoids. American Journal of Obstetrics and Gynecology 173 254-262.

Ballard PL, Kitterman JA, Bland RD, Clyman RI, Gluckman PD, Platzker ACF, Kaplan SL \& Grumbach MM 1982 Ontogeny and regulation of corticosteroid binding globulin capacity in plasma of fetal and newborn lambs. Endocrinology 110 359-366.
Barker DJP, Osmond C, Simmonds SJ \& Wield GA 1993 The relation of small head circumference and thinness at birth to death from cardiovascular disease in adult life. British Medical Journal 306 422-426.

Bell ME, Myers TR \& Myers DA 1998 Expression of proopiomelanocortin and prohormone convertase 1 and 2 in the late gestation fetal sheep pituitary. Endocrinology 139 5135-5143.

Bennett HPJ, Browne CA \& Solomon S 1981 Purification of the two major forms of rat pituitary corticotrophin using only reversed-phase liquid chromatography. Biochemistry 20 4530-4538.

Berdusco ETM, Milne WK \& Challis JRG 1994 Low-dose cortisol infusion increases plasma corticosteroid-binding globulin (CBG) and the amount of hepatic CBG mRNA in fetal sheep on day 100 of gestation. Journal of Endocrinology 140 425-430.

Berdusco ETM, Yang K, Hammond GL \& Challis JRG 1995 Corticosteroid-binding globulin $(\mathrm{CBG})$ production by hepatic and extra-hepatic sites in the ovine fetus; effects of CBG on glucocorticoid negative feedback on pituitary cells in vitro. Journal of Endocrinology 146 121-130.

Bradford MM 1976 A rapid and sensitive method for the quantitation of microgram quantities of protein utilising the principle of proteindye binding. Analytical Biochemistry 72 248-254.

Broad KD, Kendrick KM, Sirinathsinghji DJ \& Keverne EB 1993 Changes in oxytocin immunoreactivity and mRNA expression in the sheep brain during pregnancy, parturition and lactation and in response to oestrogen and progesterone. Journal of Neuroendocrinology 5 435-444.

Challis JRG, Patrick JE, Cross J, Workewych J, Manchester E \& Power S 1981 Short-term fluctuations in the concentration of cortisol and progesterone in fetal plasma, maternal plasma, and amniotic and allantoic fluids from sheep during late pregnancy. Canadian Journal of Physiology and Pharmacology 59 261-266.

Challis JRG, Nancekievill A \& Lye SJ 1985 Possible role of cortisol in the stimulation of cortisol-binding capacity in the plasma of fetal sheep. Endocrinology 116 1139-1144.

Challis JRG, Patel A \& Pomini F 1999 Prostaglandin dehydrogenase and the initiation of labour. Journal of Perinatal Medicine $\mathbf{2 7}$ 26-34.

Cudd TA \& Wood CE 1995 Secretion and clearance of immunoreactive ACTH by fetal lung. American Journal of Physiology 268 E845-E848.

Dai G, Smeekens SP, Steiner DF, McMurtry JP \& Kwok SCM 1995 Characterisation of multiple prohormone convertase PC1/3 transcripts in porcine ovary. Biochimica et Biophysica Acta 1263 $1-6$.

D’Ercole AJ 1987 Somatomedins/insulin-like growth factors and fetal growth. Journal of Developmental Physiology 9 481-495.

Dunlop SA, Archer MA, Quinlivanh JA, Beazley LD \& Newnham JP 1997 Repeated prenatal corticosteroids delay myelination in the ovine central nervous system. Journal of Maternal and Fetal Medicine 6 309-313.

Durand P, Cathiard AM, Dacheux F, Naaman E \& Saez JM 1986 In vitro stimulation and inhibition of adrenocorticotrophin release by pituitary cells from ovine fetuses and lambs. Endocrinology 118 1387-1394.

Eipper BA \& Mains RE 1980 Structure and biosynthesis of proadrenocorticotrophin/endorphin and related peptides. Endocrine Reviews 1 1-27.

French NP, Evans SF, Godfrey KM \& Newnham JP 1999 Repeated antenatal corticosteroids: size at birth and subsequent development. American Journal of Obstetrics and Gynecology 180 114-121.

Gossard FJ, Chang ACY \& Cohen SN 1986 Sequence of the cDNA encoding porcine pro-opiomelanocortin. Biochimica et Biophysica Acta 866 68-74.

Ikegami M, Jobe AH, Newnham J, Polk DH, Willet KE \& Sly P 1997 Repetitive prenatal glucocorticoids improve lung function and 
decrease growth in preterm lambs. American Journal of Respiratory and Critical Care Medicine 156 178-184.

Ivell R, Hunt N, Abend N, Brackman B, Nollmeyer D, Lamsa JC \& McCracken JA 1990 Structure and ovarian expression of the oxytocin gene in sheep. Reproduction, Fertility and Development 2 703-711.

Jacobs RA, Oosterhuis J, Porter DG, Lobb DK, Yuzpe AA \& Challis JRG 1991 Immunoreactive adrenocorticotrophin is present in the ovary and in particular the oocyte of several mammalian species. Journal of Reproduction and Fertility 91 285-291.

Jeffray TM, Matthews SG, Hammond GL \& Challis JRG 1998 Divergent changes in plasma ACTH and pituitary POMC mRNA after cortisol administration to late gestation ovine fetus. American Journal of Physiology 274 E417-E425.

Jeffray TM, Rice GE \& Challis JRG 1999 Differential effects of cortisol on POMC-derived peptides in the fetal pars distalis, lung and placenta. Journal of the Society of Gynecological Investigation 6 78A (Abstract).

Jobe AH, Wada N, Berry LM, Ikegami M \& Ervin MG 1998 Single and repetitive maternal glucocorticoid exposures reduce fetal growth in sheep. American Journal of Obstetrics and Gynecology 178 880-885.

Johnson JWC, Mitzner W, Beck JC, London WT, Sly DL, Lee PA, Khouzami VA \& Cavaliere RL 1981 Long-term effects of betamethasone on fetal development. American Journal of Obstetrics and Gynecology 141 1063-1064.

Jones CT, Gu W \& Parer JT 1989 The control of the output of corticotrophin-releasing hormone from sheep placenta. Journal of Developmental Physiology 11 121-134.

Kemppainen RJ, Clark TP, Sartin JL \& Zerbe CA 1993 Hypothalamic peptide regulation of ACTH secretion from sheep pituitary. American Journal of Physiology 265 R840-R845.

Li J, Saunders JC, Gilmour RS, Silver M \& Fowden AL 1993 Insulin-like growth factor II messenger ribonucleic acid expression in fetal tissues of the sheep during late gestation: effects of cortisol. Endocrinology 132 2083-2089.

Liggins GC 1994 The role of cortisol in preparing the fetus for birth. Reproduction, Fertility and Development 6 141-150.

Liggins GC \& Howie RN 1972 A controlled trial of antepartum glucocorticoid treatment for prevention of the respiratory distress syndrome in premature infants. Pediatrics 50 515-525.

Liggins GC, Fairclough RJ, Grieves SA, Kendall JZ \& Knox BS 1973 The mechanisms of initiation of parturition in the ewe. Recent Progress in Hormone Research 159 111-126.

Louis TM, Challis JRG, Robinson JS \& Thorburn GD 1976 Rapid increase of fetal corticosteroids after prostaglandin $\mathrm{E}_{2}$. Nature 264 797-799.

McMillen IC, Antolovich GC, Mercer JE, Perry RA \& Silver M 1990 Proopiomelanocortin messenger RNA levels are increased in the anterior pituitary of the sheep fetus after adrenalectomy in late gestation. Neuroendocrinology 52 297-302.

Marcinkiewicz M, Ramla D, Seidah NG \& Chretien M 1994 Developmental expression of the prohormone convertase PC1 and PC2 in mouse pancreatic islets. Endocrinology 135 1651-1660.

Matthews SG 1999 Hypothalamic oxytocin in the developing ovine fetus: interaction with pituitary-adrenocortical function. Brain Research 820 92-100.

Matthews SG \& Challis JRG 1995a Developmental regulation of preproenkephalin mRNA in the ovine paraventricular nucleus: effects of stress and glucocorticoids. Developmental Brain Research $\mathbf{8 6}$ 259-267.

Matthews SG \& Challis JRG 1995 begulation of CRH and AVP mRNA in the developing ovine hypothalamus: effects of stress and glucocorticoids. American Journal of Physiology 268 E1096-E1107.

Matthews SG \& Challis JRG 1997 CRH and AVP-induced changes in synthesis and release of ACTH from the ovine fetal pituitary in vitro: negative influences of cortisol. Endocrine 6 293-300.
Matthews SG, Heavens RP \& Sirinathsinghji DJ 1991 Cellular localisation of corticotrophin releasing factor mRNA in the ovine brain. Brain Research, Molecular Brain Research 11 171-176.

Matthews SG, Parrott RA \& Sirinathsinghji DJ 1993 Distribution and cellular localisation of vasopressin mRNA in the ovine brain, pituitary and pineal glands. Neuropeptides 25 11-17.

Matthews SG, Han X, Lu F \& Challis JRG 1994 Developmental changes in the distribution of proopiomelanocortin and prolactin mRNA in the pituitary of the ovine fetus and lamb. Journal of Molecular Endocrinology 13 175-185.

Matthews SG, Yang K \& Challis JRG 1995 Changes in glucocorticoid receptor mRNA in the developing ovine pituitary and the effects of exogenous cortisol. Journal of Endocrinology 144 483-490.

Meaney MJ \& Aitken DH 1985 The effects of early postnatal handling on hippocampal glucocorticoid receptor concentrations: temporal parameters. Developmental Brain Research 22 301-304.

Newnham JP, Evans SF, Godfrey ME, Huang WL, Ikegami M \& Jobe AH 1999 Maternal, but not fetal, administration of corticosteroids restricts fetal growth. Journal of Maternal and Fetal Medicine $\mathbf{8}$ 81-87.

Noda M, Furutani Y, Takahashi H, Toyosato M, Hirose T, Inayama S, Nakanishi S \& Numa S 1982 Cloning and sequence analysis of cDNA for bovine adrenal preproenkephalin. Nature 295 202-205.

Norman LJ, Lye SJ, Wlodek ME \& Challis JRG 1985 Changes in pituitary responses to synthetic ovine corticotrophin releasing factor in fetal sheep. Canadian Journal of Physiology and Pharmacology 63 1398-1403.

Phillips DIW, Barker DJP, Fall CHD, Seckl JR, Whorwood CB, Wood PJ \& Walker BR 1998 Elevated plasma cortisol concentrations: a link between low birth weight and the insulin resistance syndrome. Journal of Clinical Endocrinology and Metabolism $83757-760$.

Ratter S, Rees LH, Landon JR, Hillier K, Jansen CAM, Beck NFG, Lowe KC, Thomas AL \& Nathanielsz PW 1979 The effect of prostaglandin $\mathrm{E}_{2}$ infusion in the fetal lamb on fetal plasma ACTH, prolactin and cortisol concentrations. Prostaglandins $\mathbf{1 8}$ 101-117.

Reinisch JM, Simon NG, Karow WG \& Gandelman R 1978 Prenatal exposure to prednisone in humans and animals retards intrauterine growth. Science 202 436-438.

Sapolsky RM, Armanini MP, Packan DR, Sutton SW \& Plotsky PM 1990 Glucocorticoid feedback inhibition of adrenocorticotropic hormone secretagogue release: relationship to corticosteroid receptor occupancy in various limbic sites. Neuroendocrinology $\mathbf{5 1}$ 328-336.

Seidah NG, Fournier H, Boileau G, Benjannet S, Rondeau N \& Chretien M 1992 The cDNA structure of the porcine pre-hormone convertase PC2 and the comparative processing by PC1 and PC2 of the N-terminal glycopeptide segment of porcine POMC. FEBS Letters 310 235-239.

Uno H, Lohmiller L, Thieme C, Kemnitz JW, Engle MJ, Roecker EB \& Farrell PM 1990 Brain damage induced by prenatal exposure to dexamethasone in fetal rhesus macaques. I. Hippocampus. Developmental Brain Research 53 157-167.

Uno H, Eisele S, Sakai A, Shelton S, Baker E, Dejesus O \& Holden J 1994 Neurotoxicity of glucocorticoids in the primate brain. Hormones and Behaviour 28 336-348.

Yang K, Jones SA \& Challis JRG 1990 Changes in glucocorticoid receptor number in the hypothalamus and pituitary of the sheep fetus with gestational age and after adrenocorticotrophin treatment. Endocrinology 126 11-17.

Yang K, Challis JRG, Han VKM \& Hammond GL 1991 Proopiomelanocortin messenger RNA levels increase in the fetal sheep pituitary during late gestation. Journal of Endocrinology 131 483-489. 
Yang K, Hammond GL \& Challis JRG 1992 Characterisation of an ovine glucocorticoid receptor cDNA and developmental changes in its mRNA levels in the fetal sheep hypothalamus, pituitary gland and adrenal. Journal of Molecular Endocrinology 8 173-180.
Received 2 July 1999

Revised manuscript received 28 October 1999

Accepted 9 November 1999 